\title{
Epidemiological aspects of visceral leishmaniasis in Brazil and in international
}

\section{border regions}

\author{
Aspectos epidemiológicos da leishmaniose visceral no Brasil e em regiões de fronteira internacional \\ Aspectos epidemiológicos de la leishmaniasis visceral en Brasil y en las regiones fronterizas
}

internacionales

Recebido: 16/09/2021 | Revisado: 26/09/2021 | Aceito: 28/09/2021 | Publicado: 01/10/2021

\author{
Lara Camila de Oliveira \\ ORCID: https://orcid.org/0000-0002-1648-069X \\ Universidade Estadual do Oeste do Paraná, Brasil \\ E-mail: laracamilaenf@hotmail.com \\ Neide Martins Moreira \\ ORCID: https://orcid.org/0000-0002-5051-9295 \\ Universidade Estadual do Oeste do Paraná, Brasil \\ E-mail: neidemartinsenf@yahoo.com.br
}

\begin{abstract}
Objectives: To verify the number of visceral leishmaniasis (VL) cases in Brazil and its states and twin cities, with a focus on the state and twin city with the highest number of cases. We investigated social, demographic, laboratory and clinical aspects of these cases. Methodological design: We performed a descriptive study using a quantitative approach and data from 2010 to 2019 that were obtained through a public domain website, the Informatics Department of the Unified Health System. The incidence rate of VL cases was calculated per 100,000 inhabitants. software. Results: In Brazil, 35,886 VL cases were reported, with 2,834 cases in international border states and 148 cases in twin cities. The state and twin city with the highest number of cases were Mato Grosso do Sul (1,834 cases) and Corumbá ( 94 cases), respectively, with annual mean incidence rates of 6.4 and 8.3 cases per 100,000 inhabitants. In Mato Grosso do Sul and Corumbá, the disease was more frequent in male and brown-skinned individuals who had up to 8 years of education (age range: 1 to $>80$ years old). Most of the cases occurred in urban areas, was diagnosed by laboratory tests and evolved to cure $(\mathrm{p}<0.05)$. Conclusions: A high number of VL cases in Brazil was found during the period of study. The cases were distributed in 10 states with international borders and eight twin cities. These findings draw attention to the greater need for management programs to control and prevent VL.
\end{abstract}

Keywords: Visceral leishmaniasis; Brazil; Border areas; Health on the border; Epidemiology.

\section{Resumo}

Objetivo: verificar o número de casos de leishmaniose visceral (LV) no Brasil e estados e cidades gêmeas do país, com enfoque no estado e na cidade gêmea com maior número de casos. Investigamos aspectos sociais, demográficos, laboratoriais e clínicos desses casos. Percurso metodológico: Estudo descritivo e com abordagem quantitativa, realizado no período de 2010 a 2019, por meio do site de domínio público do Departamento de Informática do Sistema Único de Saúde. A taxa de incidência de casos de LV foi calculada por 100.000. Resultados: No Brasil foram notificados 35.886 casos de LV, 2834 casos foram em estados de fronteira internacional, sendo 148 em cidades gêmeas. O estado e cidade gêmea com maior número de casos foi Mato Grosso do Sul (MS) (1834) e Corumbá (94), com taxa média anual de 6,4 e 8,3 casos/100.000 habitantes. No MS e em Corumbá, a doença foi mais frequente no sexo masculino, pessoas de cor parda, escolaridade até 8 anos de estudo, faixa etária entre menores de um ano a maiores de 80 anos, a maioria dos casos ocorreu na zona urbana, foi diagnosticado por exames laboratoriais e com evoluiu para a cura (p<0,05). Conclusão: Foi encontrado um elevado número de casos de LV no Brasil durante o período do estudo. Os casos foram distribuídos em 10 estados com fronteiras internacionais e oito cidades gêmeas. Esses achados chamam a atenção para a maior necessidade de programas de manejo integrado para controlar e prevenir a LV.

Palavras-chave: Leishmaniose visceral; Brasil; Áreas de fronteira; Saúde na fronteira; Epidemiologia.

\section{Resumen}

Objetivo: Verificar el número de casos de leishmaniasis visceral (LV) en Brasil y en los estados y ciudades gemelas del país, enfocándose en el estado y en la ciudad gemela con mayor número de casos. Investigamos aspectos sociales, demográficos, de laboratorio y clínicos de estos casos. Trayectoria metodológica: Estudio descriptivo con abordaje cuantitativo, realizado de 2010 a 2019, a través del sitio web de dominio público del Departamento de Informática del Sistema Único de Salud. La tasa de incidencia de casos de LV se calculó por 100.000. Resultados: En Brasil se reportaron 35,886 casos de LV, 2834 casos ocurrieron en estados fronterizos internacionales, siendo 148 en Twin Cities. 
El estado y ciudad hermanada con mayor número de casos fueron Mato Grosso do Sul (1834) y Corumbá (94), con una tasa promedio anual de 6,4 y 8,3 casos/100.000 habitantes. En Mato Grosso do Sul y Corumbá, la enfermedad fue más frecuente en varones, gente morena, educación hasta 8 años de estudio, grupo de edad desde menos de un año hasta más de 80 años. La mayoría de los casos ocurrieron en áreas urbanas, fueron diagnosticados mediante pruebas de laboratorio y progresaron hasta la curación ( $\mathrm{p}<0.05$ ). Conclusión: Se encontró un alto número de casos de LV en Brasil durante el período de estudio. Los casos se distribuyeron en 10 estados con fronteras internacionales y ocho ciudades gemelas. Estos hallazgos destacan la mayor necesidad de programas de gestión integrados para controlar y prevenir la LV.

Palabras clave: Leishmaniasis visceral; Brasil; Zonas fronterizas; Salud fronteriza; Epidemiología.

\section{Introduction}

Leishmaniasis is the second most important group among vector-borne diseases in Brazil, second only to dengue in terms of the number of cases and emergence of epidemics (Brasil, 2014). Leishmaniasis is considered a neglected disease because it is endemic among more vulnerable populations, with unacceptable morbidity and mortality and lower investments in research, drug production, and control interventions (Valverde, 2021).

Visceral leishmaniasis (VL) is the most severe clinical form of leishmaniasis. It is classified as a chronic and systemic disease that, when undiagnosed and untreated, is fatal in more than 95\% of cases (Maia-Elkhoury et al., 2021). Transmission to humans and dogs, the latter of which is the main reservoir (Dantas-Torres et al., 2019), occurs through bites of infected females of the vector species Lutzomyia longipalpis (because of its ease of adaptation to peridomiciles and a wide range of temperatures) and Lutzomyia cruzi (Brasil, 2017).

Even with actions of the Visceral Leishmaniasis Surveillance and Control Program (Brasil, 2016a) that targets entomological and animal reservoirs and the treatment of diagnosed human cases, Brazil still has approximately $96 \%$ of VL cases in Latin America (Maia-Elkhoury et al., 2021). Thus, one can question whether these actions are indeed sufficiently effective to reduce the incidence of VL in Brazil (Costa et al., 2018; Salomón et al., 2015; Oliveira et al., 2016; Lopez et al., 2021).

The continual increase in the incidence of VL in several Brazilian regions can be attributed to the migration of people from rural to urban areas, deforestation, and the construction of large projects that impact the environment and cause the resettlement of people from one place to another. These people often take their pets with them, leading to a disorderly increase in deficient sanitary conditions where the vector L. longipalpis has successfully settled (Costa et al., 2018; Salomón et al., 2015). This situation represents a major challenge to controlling VL in urban areas.

Additionally, sandflies and dogs (specifically dogs that live on the street) circulate freely with no restrictions, thereby favoring the spread of VL. Several studies have reported the presence of sandflies in the border region, especially the species Lutzomyia cruzi (Oliveira et al., 2016), and dogs that are diagnosed with leishmaniasis (Lopez et al., 2021). Therefore, international border areas (i.e., areas with at least two international territories) can generate situations of vulnerability to health of the population (Pêgo \& Moura, 2018). These areas require further study to contribute to the implementation of preventive measures that specifically target VL and control vectors (e.g., dogs).

The geographical environment that best characterizes a border area consists of "twin cities" (i.e., municipalities, cities, or towns with corresponding cities in a neighboring country). Depending on how these twin cities are connected (e.g., by land, a bridge over a river, or a river without a bridge), the flow of people between these cities and their interactions can increase or decrease (Brasil, 2016b).

Understanding the spread of human VL cases and possible factors that contribute to its spread in Brazil and in border regions is important for implementing more effective strategies, including joint policies and actions with neighboring countries (Costa et al., 2018). The present study sought to verify the number of human VL cases in Brazil and its states and twin cities, with a focus on the state and twin city with the highest number of cases and social, epidemiological, demographic, laboratory 
and clinical aspects.

\section{Methodological design}

\section{Type of study}

This was an epidemiological, observational, descriptive, retrospective, cross-sectional study that was designed based on secondary data (Silva, 2014) on the number of human VL cases in Brazil and its states and twin cities that were collected from 2010 to 2019 , with a focus on the state and twin city with the highest number of cases.

\section{Data source}

The data were obtained through the public domain website of the Information Technology Department of the Unified Health System (DATASUS), at the electronic address (http://www.datasus.gov.br). After accessing the address, the steps are as follows: epidemiological and morbidity; notification diseases and injuries - 2007 onwards; in this case, visceral leishmaniasis; Brazil by region, Federative Unit and municipality, where different options appear according to the objectives of the study, as well as the years to be considered in the research.

\section{Characterization of the study area}

Brazil is located in Latin America. It is the fifth largest country in the world and has a territory of approximately 8,510,345.538 $\mathrm{km}^{2}$, an estimated population of approximately 211,755,692 inhabitants in 2020, and a demographic density of 22.43 inhabitants $/ \mathrm{km}^{2}$ (IBGE, 2020). The country has 33 twin cities that are distributed in the states of Acre, Amazonas, Amapá, Mato Grosso do Sul, Paraná, Rondônia, Roraima, Rio Grande do Sul, Santa Catarina, and Mato Grosso (Brasil, 2019). .

\section{Inclusion criteria}

We included human VL cases in Brazil and its states and twin cities, with a focus on the state and twin city with the highest number of cases, in the period from 2010 to 2019.

\section{Study variables}

The dependent variable was number of human VL cases in Brazil and its states and twin cities, with a focus on the state and twin city with the highest number of reported cases. The independent variables were gender, race/skin color, education, age group, autochthony of the case, urban/rural area, laboratory and clinical aspects (i.e., case evolution).

\section{Data analysis}

The data were collected, imported into Microsoft Excel, organized into tables and graphs, and expressed as absolute frequency and relative frequency for better visualization of the results.

The incidence rate of VL cases between 2010 and 2019 was calculated for the state and twin city with the highest number of cases, dividing the number of new cases by the exposed population, multiplied by 100,000. For this purpose, population data obtained from information from population censuses in Mato Grosso do Sul and Corumbá 2010 were considered, through the website of the Brazilian Institute of Geography and Statistics (www.ibge.gov.br) (Instituto Brasileiro de Geografia e Estatística [IBGE], 2010).

All variables surveyed were statistically analyzed. Therefore, the distribution of data was initially verified with the Shapiro-Wilk test. Since the data presented an unspecified distribution, the non-parametric Mann-Whitney test was used (Ayres et al., 2003). A significance level of 5\% and the Minitab 18 program were used. 


\section{Ethical aspects}

Because this was a secondary data analysis, no registration from any research ethics committee was required, with a waiver of consideration according to ethical standards that were established by Resolution No. 510 of 2016, of the National Health Council of Brazil, which determines specific ethical guidelines for the human and social sciences (Brasil, 2016c).

\section{Results}

According to the time series of VL in Brazil between January 2010 and December 2019, 35,886 human VL cases were reported in the Notifiable Diseases Information System (Sistema de Informações dos Agravos de Notificação [SINAN]), of which 2,834 cases were in states with international borders. The state of Mato Grosso do Sul had the highest number of notifications (Table 1).

Table 1. Distribution of human visceral leishmaniasis cases in Brazilian states with international borders (2010-2019).

\begin{tabular}{lc}
\hline \multicolumn{1}{c}{ Notification location } & No. of cases \\
\hline Mato Grosso do Sul & 1,834 \\
Pará & 347 \\
Mato Grosso & 317 \\
Roraima & 217 \\
Paraná & 50 \\
Rio Grande do Sul & 34 \\
Santa Catarina & 14 \\
Amazonas & 9 \\
Rondônia & 9 \\
Amapá & 3 \\
Acre & - \\
\hline Total & $\mathbf{2 , 8 3 4}$ \\
\hline
\end{tabular}

Source: Based on data from the Notifiable Diseases Information System, Ministry of Health, Brazil.

Among the 2,834 VL cases in states with international borders, 148 were in twin cities $(0.4 \%)$. The city of Corumbá had the highest number of notifications (Table 2).

Table 2. Distribution of human visceral leishmaniasis cases in Brazilian twin cities in each Brazilian state with an international border (2010-2019).

\begin{tabular}{llc}
\hline \multicolumn{2}{c}{ Notification location } & No. of cases \\
\hline State & Twin city & $\mathbf{9 4}$ \\
\multirow{3}{*}{ Mato Grosso do Sul } & Corumbá & $\mathbf{1 4}$ \\
& Ponta Porã & $\mathbf{4}$ \\
\hline Paraná & Bela Vista & $\mathbf{2 3}$ \\
\hline \multirow{2}{*}{ Rio Grande do Sul } & Foz do Iguaçu & $\mathbf{6}$ \\
& São Borja & 3 \\
\hline Roraima & Uruguaiana & $\mathbf{2}$ \\
\hline & Itaqui & $\mathbf{2}$ \\
\hline & Pacaraíma & $\mathbf{1 4 8}$ \\
\hline
\end{tabular}

Source: Based on data from the Notifiable Diseases Information System, Ministry of Health, Brazil. 
Table 3 shows that the number of human VL cases in Mato Grosso do Sul from 2010 to 2013 was higher, followed by a subsequent reduction. The same happened with incident rates: 8.0, 9.9, 10.5, and 8.3 cases per 100,000 inhabitants, with an annual mean incidence rate of 6.4 cases/100,000 inhabitants (Table 3).

In Corumbá, the number of VL cases remained constant between 2010 and 2013, fluctuated with little variability between 2014 and 2016, was the highest between 2017 and 2018, and then slightly decreased in 2019 (Table 3). Of the total number of notified cases, 91 were autochthonous. The annual mean incidence rate was 8.3 cases/100,000 inhabitants. In 2017 and 2018, the mean incidence rates were 16.9 and 13.3 cases per 100,000 inhabitants (Table 3).

Table 3. Number of cases and incidence rate* of visceral leishmaniasis according to notification year in the state of Mato Grosso do Sul and municipality of Corumbá (2010-2019).

\begin{tabular}{clccc}
\hline $\begin{array}{c}\text { Notification } \\
\text { year }\end{array}$ & \multicolumn{5}{c}{ Notification location } \\
\hline & Mato Grosso do Sul & \multicolumn{3}{c}{ Corumbá } \\
\hline 2010 & 225 & 8.0 & 6 & 5.3 \\
2011 & 280 & 9.9 & 8 & 7.1 \\
2012 & 297 & 10.5 & 5 & 4.4 \\
2013 & 235 & 8.3 & 4 & 3.5 \\
2014 & 170 & 6.0 & 11 & 9.8 \\
2015 & 125 & 4.4 & 6 & 5.3 \\
2016 & 141 & 5.0 & 9 & 8.0 \\
2017 & 140 & 4.9 & 19 & 16.9 \\
2018 & 110 & 3.9 & 15 & 13.3 \\
2019 & 111 & 3.9 & 11 & 9.8 \\
\hline Total & $\mathbf{1 , 8 3 4}$ & $\mathbf{6 4 . 8}$ & $\mathbf{9 4}$ & $\mathbf{8 3 . 4}$ \\
\hline
\end{tabular}

Source: Based on data from the Notifiable Diseases Information System, Ministry of Health, Brazil. *Per 100,000 inhabitants.

The disease was more frequent in males ( $\mathrm{n}=1,175$ and 61), corresponding to $64.0 \%$ of cases in Mato Grosso do Sul and $65.0 \%$ of cases in Corumbá ( $\mathrm{p}<0.05$ ). With regard to race/skin color, $8.7 \%$ and $1.0 \%$ of the research forms $(\mathrm{n}=160$ and 1$)$ were blank or marked unknown, with a higher proportion of self-declared brown-skinned people $(\mathrm{p}=0.0001)$, representing $52.9 \%(\mathrm{n}$ $=972)$ and $76.7 \%(n=72)$ of VL cases. No difference was found in the comparison between the number of people who selfdeclared as white- and brown-skinned $(\mathrm{n}=972 / 547, \mathrm{p}>0.05)$ in Mato Grosso do Sul (Table 4).

With regard to education, $26.8 \%(n=492)$ and $45.7 \%(n=43)$ were in the "not applicable" group at the time of notification in Mato Grosso do Sul and Corumbá, respectively, possibly because of the high number of cases in children under 4 years old $(25.2 \%$ and $42.5 \%$, respectively). Among VL patients, $2.0 \%(\mathrm{n}=37)$ and $2.1 \%(\mathrm{n}=2)$ declared themselves illiterate, $34.0 \%(\mathrm{n}=624)$ and $29.7 \%(\mathrm{n}=28)$ had up to 8 years of education, $13.9 \%(\mathrm{n}=256)$ and $12.7 \%(\mathrm{n}=12)$ had more than 8 years of education, and $23.3 \%(\mathrm{n}=425)$ and $9.8 \%(\mathrm{n}=9)$ were "unknown." A greater number of human VL cases was observed in the group who had up to 8 years of education $(\mathrm{p}=0.0001$; Table 4$)$.

Human VL cases ranged from under 1 year old $(n=141)$ to over 80 years old $(n=41)$ in Mato Grosso do Sul and from under 1 year old $(n=18)$ to 79 years old $(n=4)$ in Corumbá, with $25.2 \%(n=461)$ and $42.5 \%(n=40)$ of the patients aged up to 4 years old and $48.1 \%(n=884)$ and $33.9 \%(n=32)$ aged between 20 and 59 years old $(\mathrm{p}<0.05)$. No difference was found in the comparison between the number of people aged 1-4 years old and 40-59 years old $(n=320 / 469$, $p>0.05)$ or between those aged under 1-4 years old $(n=18 / 22)$ and 20-59 years $(n=17 / 15)$ in Mato Grosso do Sul and Corumbá $($ Table 4).

With regard to the area of residence, most cases occurred in urban areas, representing $93.3 \%(\mathrm{n}=1,711)$ of the total in Mato Grosso do Sul and 85.1\% $(\mathrm{n}=80)$ of the total in Corumbá $(\mathrm{p}=0.0001)$. Only $4.1 \%(\mathrm{n}=76)$ and $3.1 \%(n=3)$ were recorded in rural areas (Table 4). 
Table 4. Characteristics of people with visceral leishmaniasis in the state of Mato Grosso do Sul and municipality of Corumbá (2010-2019).

\begin{tabular}{|c|c|c|c|c|c|c|}
\hline \multirow{3}{*}{ Variable } & \multicolumn{6}{|c|}{ Notification location } \\
\hline & \multicolumn{3}{|c|}{ Mato Grosso do Sul } & \multicolumn{3}{|c|}{ Corumbá } \\
\hline & $A F$ & $R F(\%)$ & $\bar{p}$ & $A F$ & $R F(\%)$ & $\bar{p}$ \\
\hline Gender & & & $0.014 *$ & & & 0.039* \\
\hline Female & 658 & 36.0 & & 33 & 35.1 & \\
\hline Male & 1,175 & 64.0 & & 61 & 65.0 & \\
\hline Race/Skin color & & & $0.0001 *$ & & & $0.0001 *$ \\
\hline White & $547^{\mathrm{a}}$ & 30.0 & & 16 & 17.0 & \\
\hline Black & 123 & 6.7 & & 5 & 5.3 & \\
\hline Brown & $972^{\mathrm{a}}$ & 52.9 & & 72 & 76.7 & \\
\hline Indigenous & 17 & 0.9 & & - & - & \\
\hline Asian & 15 & 0.8 & & - & - & \\
\hline Unknown/Blank & 160 & 8.7 & & 1 & 1.0 & \\
\hline Education & & & 0.0001* & & & $0.0001 *$ \\
\hline Illiterate & 37 & 2.0 & & 2 & 2.1 & \\
\hline$\leq 8$ years & 624 & 34.0 & & 28 & 29.7 & \\
\hline$>8$ years & 256 & 13.9 & & 12 & 12.7 & \\
\hline Unknown/blank & 425 & 23.3 & & 9 & 9.8 & \\
\hline Not applicable & 492 & 26.8 & & 43 & 45.7 & \\
\hline Age group & & & $0.0001 *$ & & & $<0.05 *$ \\
\hline$<1$ year & 141 & 7.6 & & $18^{\mathrm{a}}$ & 19.1 & \\
\hline $1-4$ years & $320^{\mathrm{a}}$ & 17.6 & & $22^{\mathrm{a}}$ & 23.4 & \\
\hline $5-9$ years & 75 & 4.0 & & 3 & 3.1 & \\
\hline 10-14 years & 45 & 2.8 & & 4 & 4.2 & \\
\hline $15-19$ years & 83 & 4.5 & & 4 & 4.2 & \\
\hline 20-39 years & 415 & 22.6 & & $17^{\mathrm{a}}$ & 18.0 & \\
\hline $40-59$ years & $469^{\mathrm{a}}$ & 25.5 & & $15^{\mathrm{a}}$ & 15.9 & \\
\hline $60-64$ years & 79 & 4.3 & & 5 & 5.3 & \\
\hline $65-69$ years & 69 & 3.7 & & 2 & 2.1 & \\
\hline 70-79 years & 94 & 5.1 & & 4 & 4.2 & \\
\hline$\geq 80$ years & 41 & 2.2 & & - & - & \\
\hline Unknown/White & 3 & 0.1 & & - & - & \\
\hline Area & & & $0.0001 *$ & & & $0.0001 *$ \\
\hline Rural & 76 & 4.1 & & 3 & 3.1 & \\
\hline Urban & 1,711 & 93.3 & & 80 & 85.1 & \\
\hline Peri-urban & 3 & 0.2 & & 2 & 2.1 & \\
\hline Unknown/blank & 44 & 2.4 & & 9 & 9.5 & \\
\hline
\end{tabular}

$\mathrm{AF}$, absolute frequency; RF, relative frequency; ${ }^{*} p<0.05$ (Mann-Whitney test). Values with the same letter (a) indicate no significant difference ( $p>0.05$, Mann-Whitney test). (-), not calculated. Source: Data from the Notifiable Diseases Information System, Ministry of Health, Brazil.

The diagnosis of VL cases reported in Mato Grosso do Sul and in Corumbá was performed by means of parasitological examination, with positivity of $26.7 \%(\mathrm{n}=491)$ and $41.5(\mathrm{n}=39)(\mathrm{p}<0.05)$ and of the immunological exam, indirect immunofluorescence (IIF), with positivity of $43.7 \%(\mathrm{n}=801)(\mathrm{p}=0.0003)$ and $45.7 \%(\mathrm{n}=43)(\mathrm{p}>0.05)$, being that, $88.8 \%(\mathrm{n}$ $=1629)$ and $77.7 \%(\mathrm{n}=73)$ of the cases were confirmed by laboratory examination and $11.2 \%(\mathrm{n}=205)$ and $22.3 \%(\mathrm{n}=21)$ by criteria clinical-epidemiological ( $<$ 0.05) (Table 5).

With regard to clinical evolution, most of the cases evolved to a cure $(80.9 \%(n=1,484)$ in Mato Grosso do Sul and $76.5 \%(\mathrm{n}=72)$ in Corumbá; $\mathrm{p}=0.0001$; Table 5).

With regard to the number of deaths that were attributable to VL, 6.7\% $(\mathrm{n}=124)$ were reported in Mato Grosso do Sul, and $15.9 \%(\mathrm{n}=15)$ were reported in Corumbá $(\mathrm{p}=0.0001$; Table 5). 
Table 5. Laboratory and clinical characteristics of people with visceral leishmaniasis, in the state of Mato Grosso do Sul and municipality of Corumbá (2010-2019).

\begin{tabular}{|c|c|c|c|c|c|c|}
\hline \multirow{3}{*}{ Variable } & \multicolumn{6}{|c|}{ Notification location } \\
\hline & \multicolumn{3}{|c|}{ Mato Grosso do Sul } & \multicolumn{3}{|c|}{ Corumbá } \\
\hline & $A F$ & $R F(\%)$ & $\bar{p}$ & $A F$ & $R F(\%)$ & $\bar{p}$ \\
\hline \multicolumn{2}{|c|}{ Parasitological diagnosis } & & 0.0019* & & & $0.0003 *$ \\
\hline Positive & 491 & 26.7 & & 39 & $41.5^{\mathrm{a}}$ & \\
\hline Negative & 197 & 10.7 & & 11 & 11.7 & \\
\hline Unrealized & 1141 & 62.3 & & 44 & $46.8^{\mathrm{a}}$ & \\
\hline Ignored/white & 5 & 0.3 & & - & - & \\
\hline \multicolumn{2}{|c|}{ Immunological diagnosis ${ }^{b}$} & & $0.0003 *$ & & & 0.1212 \\
\hline Positive & 801 & $43.7^{\mathrm{a}}$ & & 43 & 45.7 & \\
\hline Negative & 199 & 10.8 & & 14 & 14.9 & \\
\hline Unrealized & 829 & $45.2^{\mathrm{a}}$ & & 37 & 39.4 & \\
\hline Ignored/white & 5 & 0.3 & & - & - & \\
\hline \multicolumn{2}{|c|}{ Confirmation criteria for $\mathrm{LV}$} & & $0.0002 *$ & & & 0.0019* \\
\hline Laboratory & 1629 & 88.8 & & 73 & 77.7 & \\
\hline $\begin{array}{l}\text { Clinical- } \\
\text { epidemiological }\end{array}$ & 205 & 11.2 & & 21 & 22.3 & \\
\hline Clinical evolution & & & $0.0001 *$ & & & $0.0001 *$ \\
\hline Cure & 1.484 & 80.9 & & 72 & 76.5 & \\
\hline Abandonment & 25 & 1.3 & & - & - & \\
\hline Death due to VL & 124 & 6.7 & & 15 & 15.9 & \\
\hline $\begin{array}{l}\text { Death due to other } \\
\text { disease }\end{array}$ & 100 & 5.7 & & 5 & 5.3 & \\
\hline Transfer & 42 & 2.2 & & 2 & 2.1 & \\
\hline Unknown/blank & 59 & 3.2 & & - & - & \\
\hline
\end{tabular}

AF. absolute frequency; RF. relative frequency; ${ }^{b}$ Indirect immunofluorescence technique. ${ }^{*} p<0.05$ (MannWhitney test). Values with the same letter $\left({ }^{\mathrm{a}}\right)$ indicate no significant difference $(p>0.05$. Mann-Whitney test). (-). not calculated. Source: Data from the Notifiable Diseases Information System. Ministry of Health. Brazil.

\section{Discussion}

Visceral leishmaniasis is the most severe form of leishmaniasis and almost always fatal if not diagnosed and treated. It is endemic in 12 countries on the South American continent. From 2001 to 2017, 59,769 new cases were recorded in these countries, with an average of 3,516 cases annually (Maia-Elkhoury et al., 2021). Approximately 96\% (57,582) of the cases were concentrated in Brazil, thus corroborating the high number of cases in 2010-2019 that were identified in the present study, with an annual average of 3,588 cases. However, geographical expansion has been observed in other South American countries, including Argentina, Colombia, Paraguay, and Venezuela (Maia-Elkhoury et al., 2021).

According to a bibliographic review of the profile of VL in Brazil (Lemos, Sousa \& Silva, 2019), the high percentage of cases in Brazilian regions is attributable to a progressive increase in urban areas. Leishmaniasis is associated with anthropogenic environmental transformations that allow the adaptation and formation of mosquito breeding sites that are encouraged by socioeconomic factors that direct a significant proportion of the population to migrate to urban peripheries that have relatively precarious housing and sanitary infrastructure conditions. Deforestation and large fires also favor displacement of the transmission vector to urban centers, consequently exposing the population to vector transmission (Costa et al., 2018; Salomón et al., 2015; Ortiz \& Anversa 2015).

International border areas can also generate situations of vulnerability to the health of populations (Pêgo \& Moura, 2018), especially in the presence of sandflies and dogs (specifically those that live on the street) (Oliveira et al., 2016; Lopez et al., 2021). Thus, understanding the epidemiological profile of VL in border regions provides better knowledge about the disease and supports managers and health professionals in the construction of measures, as well as in directing and prioritizing areas to 
be worked (Maia-Elkhoury et al., 2021).

In the present study, the most affected state with an international border and twin city were Mato Grosso do Sul and Corumbá, respectively. According to epidemiological evidence, the presence of the parasite in these regions can be attributed to the construction of a railway that originated in Bolivia, a highway that was built between Três Lagoas and Corumbá, and a natural gas pipeline that was built between Bolivia and Brazil (Lopez et al., 2021).

Consequently, VL became urbanized through changes in the vector's behavior that resulted from socioenvironmental changes, specifically deforestation and the migration process. Deforestation reduced access to animals that were normally a source of food for the vector insect. Dogs and humans then emerged as the most accessible alternative food sources for the vector. The migratory process took human and canine populations from rural areas where the disease was endemic to cities' peripheral areas (Costa et al., 2018; Salomón et al., 2015; Oliveira et al., 2016). Consequently, the state of Mato Grosso do Sul began to be considered a new Brazilian endemic region for VL (Lopez et al., 2021).

According to an epidemiological bulletin on VL in Mato Grosso do Sul between 2011 and July 2020, 1,741 cases were confirmed, with an annual average of 174.1 cases and 124 deaths (Bogiani \& Oliveira, 2020). In the municipality of Campo Grande, Mato Grosso do Sul, from 2001 to 2018, 1,855 VL cases were reported, with an annual average of 103.0 cases and annual average incidence rate of 13.23 cases/100,000 inhabitants, demonstrating the rapid transition from epidemic to endemic (Oliveira et al., 2020). These data corroborate the present findings. From 2010 to 2019, the annual average was calculated to be 183.4 human cases, with an incidence rate that ranged from 3.9 to 10.5 cases per 100,000 inhabitants in the state. From 2010 to 2013, the number of human VL cases was higher, which subsequently decreased.

For the municipality of Corumbá, the present study found an annual average of 9.4 cases, with incidence rates that ranged from 3.5 to 16.9 cases per 100,000 inhabitants in the region. The number of cases remained constant between 2010 and 2013, fluctuated with little variability between 2014 and 2016, was the highest between 2017 and 2018, and slightly decreased in 2019. Calculations of the incidence rate of cases remains an important tool for surveillance because it provides better knowledge about VL and guides health managers and professionals in adopting actions that may be useful (Maia-Elkhoury et al., 2021).

We cannot definitively explain the variations in incidence rates that were found in the present study. The Leishmania parasite presents wide complexity in transmission dynamics (Courtenay et al., 2017). Various factors can be involved and various hypotheses can be posited, including the cyclical nature of the disease, particularities of its pathogenesis (e.g., its indeterminate incubation period and asymptomatic and subclinical forms) (Toledo et al., 2017; Zuben \& Donalísio, 2016). Furthermore, the high adaptability of the vector insect that is responsible for transmission of the disease should also be considered (Rocha, 2019).

Visceral leishmaniasis is transmitted through bites of infected female sandflies, especially Lutzomyia longipalpis and Lutzomyia cruzi (Rocha, 2019). A study in the municipality of Corumbá that evaluated the seasonal distribution of sandflies over a 2-year period (from April 2012 to March 2014) found that the monthly distribution of sandflies was $93.9 \%$ for L. cruzi (Oliveira et al., 2016).

Additionally, an epidemiology research study of VL in the municipality of Três Lagoas, Mato Grosso do Sul, investigated 6,469 dogs for the presence of canine VL between 2016 and 2019, of which 52.6\% were positive10. In the border area of Corumbá and in Paraguay and Bolivia (Corumbá, 2021), sandflies and dogs (specifically those that live on the street) circulate freely between the borders. Therefore, there is no barrier to where they may roam, which contributes to spread of the disease in these areas (Pêgo \& Moura, 2018).

As for VL preventive measures, the Surveillance and Control Program determines the following actions when directed at the human population: use of mosquito nets, screens on doors and windows and use of repellents; vector-directed: environmental management and sanitation, through urban cleaning, disposal and proper disposal of organic solid waste, 
elimination of a source of moisture and non-permanence of domestic animals in the home; directed to dogs: control of the errant canine population, in cases of animal donation, perform a serological test for VL before donation, use of screens in individual or collective kennels and collars impregnated with 4\% deltamethrin for dogs (Brasil, 2016a).

However, the number and incidence of human cases of VL reported in Mato Grosso do Sul and Corumbá, the high percentage of sandfly L. cruzi, in Corumbá (Lopez et al., 2021) and the positivity found for canine VL in Três Lagoas (Pêgo \& Moura, 2018), indicate failure in the realization of preventive measures and require actions effective measures to combat and eliminate the disease.

With regard to sociodemographic aspects, according to the Epidemiological Bulletin on VL that was published in 2020, the most affected age group in the state of Mato Grosso do Sul was 35-49 years old (22.9\%), followed by 1-4 years old (17.1\%), most of whom were male (65.0\%) (Bogiani \& Oliveira, 2020). In Campo Grande, the most affected age groups were children up to 5 years old and adults over 40 years old, and the highest incidence was in males (Oliveira et al., 2020). In the present study, the most affected age groups in Mato Grosso do Sul and Corumbá were up to 5 years old and 20-59 years old, and the most affected were also male $(\mathrm{p}<0.05)$.

The frequency of cases in children compared with adults may be related to the fact that children have more direct contact with reservoir and vector animals and have immature immune function and nutritional deficits (Oliveira et al., 2014). The predominance of males may be attributable to behavioral differences relative to females, given the higher presence of men in areas with a higher risk of sandfly bites (Araújo et al., 2016).

As for to race/skin color, most cases were brown-skinned individuals in the state of Mato Grosso do Sul and municipality of Corumbá ( $\mathrm{p}=0.0001$ ), which is consistent with observations in Palmas-Tocantins, Brazil, between 2002 and 2013, where 71.4\% of people declared themselves to be brown-skinned (Silva et al., 2017).

With regard to education, most people in Mato Grosso do Sul and Corumbá had up to 8 years of education $(\mathrm{p}=0.0001)$, suggesting socioeconomic vulnerability that is usually associated with VL (Luz et al., 2018). This finding shows that a low level of education can influence knowledge and health practices related to prevention (Menezes et al., 2016).

As for to the place of residence, the wide distribution of VL in urban areas $(p=0.0001)$ in Mato Grosso do Sul and Corumbá has been an epidemiological reality that requires a new rationale for disease surveillance and control systems. The present findings corroborate other studies, in which the predominance of VL cases also occurred in urban areas as a result of destruction of the vectors' natural habitats and environmental conditions that were favorable to spread of the disease, such as a precarious sanitary infrastructure and high population density with lower purchasing power (Silva et al., 2017; Barbosa, 2016; Cardim et al., 2016).

With regard to laboratory, parasitological and immunological tests used to diagnose VL cases reported in Mato Grosso do Sul and Corumbá, the IIF serological test and the bone marrow and spleen aspirate that usually shows the presence of amastigotes of the parasite, are generally recommended for diagnosing VL (Brasil, 2016a; Rey, 2010), which provided confirmation of $88.8 \%$ and $77.7 \%$ of cases, and only $22.3 \%$ of case by criteria clinical-epidemiological ( $<<0.05$ ).

As for the drug used for treatment, this information was not available on SINAN, however, in Brazil, the drug of first choice is the pentavalent antimonial $\left(\mathrm{Sb}^{+5}\right)$, $\mathrm{n}$-methyl-glucamine antimoniate, distributed by the Ministry of Health in $1 \mathrm{ml}$ ampoules, containing $81 \mathrm{mg}$ of $\mathrm{Sb}^{+5}$. It is recommended to treat $\mathrm{VL}$ with a dose of $20 \mathrm{mg}$ of $\mathrm{Sb}^{+5} \mathrm{~kg} / \mathrm{day}$, with intravenous-IV or intramuscular-IM application, for 20 to 40 days, using the maximum limit of 2 to 3 ampoules/day of product with favorable cure rates (Brasil, 2016a).

With regard to clinical and epidemiological profiles, the frequencies of cure above $81.0 \%$ and $72.0 \%$ in Mato Grosso do Sul and Corumbá, respectively, and frequencies of death of $7.4 \%$ and $16.0 \%(\mathrm{p}=0.0001)$ are consistent with a study of the epidemiology of VL in the municipality of Três Lagoas, Mato Grosso do Sul, where 84.8\% of 211 human cases diagnosed 
between 2000 and 2019 evolved to a cure and 10.4\% evolved to death (Lopez et al., 2021), indicating that among the actions of the VL Surveillance and Control Program, the treatment is being carried out effectively (Brasil, 2016a).

The present study has limitations. The use of retrospective secondary data and quality of the information that was collected on the notification forms are possible weaknesses. Nonetheless, studies of the epidemiological profile of VL that use retrospective designs and secondary data (Araújo et al., 2016; Silva et al., 2017; Barbosa, 2016; Cardim et al., 2016; Cavalcanti et al., 2017; Cavalcante et al., 2020; Graepp-Fontoura et al., 2020) can indeed support the planning of expanded and structured public policies that can guide current strategies to control the disease and identify possible high-risk areas, with the goal of preventing leishmaniasis.

\section{Conclusions}

A high number of human VL cases was reported in Brazil between 2010 and 2019, with a wide distribution in 10 states with international borders and an emphasis on eight twin cities. Of the states with international borders and twin cities, Mato Grosso do Sul and Corumbá were the most affected by the disease in the period of study, with an annual mean incidence rate of 6.4 and 8.3 cases $/ 100,000$ inhabitants.

In Mato Grosso do Sul and Corumbá, the disease was more frequent in males, in children under 4 years of age, and in adults 20-59 years of age. The highest frequency was found among people who self-identified as brown-skinned and who had 8 years of education.

Most cases occurred in urban areas, was diagnosed by laboratory tests and progressed to cure. However, the high number of notified VL cases requires greater attention from integrated disease management programs. Visceral leishmaniasis is difficult to control and prevent and has a rapid and wide geographic dispersion, mainly in border areas where vectors and dogs (specifically those that live on the street) move freely between countries.

Thus, works about spatial analysis to identify the places with the highest occurrence of VL in Mato Grosso do Sul and Corumbá, with the objective of guiding the implementation of prevention and control policies aimed at needy regions, are important.

\section{References}

Ayres, M., Ayres, M., Ayres, D. L., \& Santos, A. A. S. (2003). BioEstat 5.0: aplicações estatísticas nas áreas das ciências biológicas e médicas. Sociedade Civil Mamirauá.

Barbosa, I. R. (2016). Leishmaniose Visceral Humana no município de Natal-RN: análise clínico-epidemiológica e espacial. Revista Ciência Plural, 2(1), 89101.

Bogiani, P. A., \& Oliveira, R. O. (2020). Boletim epidemiológico: leishmaniose visceral. https://www.vs.saude.ms.gov.br/wp-content/uploads/2020/08/BoletimEpidemiol\%C3\%B3gico-Leishmaniose-SE-32.pdf.

Brasil. (2014). Organização Mundial da Saúde alerta para doenças transmitidas por vetores e Escola Nacional de Saúde Pública lista as mais comuns no Brasil. Brasil, Fundação Osvaldo Cruz; 2021. https://portal.fiocruz.br/noticia/oms-alerta-para-doencas-transmitidas-por-vetores-e-ensp-lista-mais-comuns-no-brasil.

Brasil. (2016a). Ministério da Saúde. Guia de Vigilância em Saúde. Brasília - Distrito Federal. http://portalarquivos2.saude.gov.br/images/pdf/2016/novembro/18/Guia-LV-2016.pdf.

Brasil. (2016b). Ministério da Integração. Estabelece o conceito de "cidades gêmeas" nacionais, os critérios adotados para essa definição e lista todas as cidades brasileiras por estado que se enquadram nesta condição. Portaria no 213, de 19 de julho de 2016. https://www.in.gov.br/materia//asset_publisher/Kujrw0TZC2Mb/content/id/21772550/do1-2016-07-20-portaria-n-213-de-19-de-julho-de-2016-21772471.

Brasil. (2016c). Resolução $\mathrm{N}^{\mathrm{o}}$ 510, de 7 de abril de 2016. Diário Oficial da União. Ministério da Saúde/Conselho Nacional de Saúde. https://www.in.gov.br/materia/-/asset_publisher/Kujrw0TZC2Mb/content/id/22917581.

Brasil. (2017). Ministério da saúde. Guia de vigilância em saúde. Brasília - Distrito Federal. https://www.hc.ufu.br/sites/default/files/tmp//volume_3_guia_de_vigilancia_em_saude_2017.pdf.

Brasil. (2019). Comissão Permanente para o Desenvolvimento e a Integração da Faixa de Fronteira. Ministério do Desenvolvimento Regional. https://www.gov.br/mdr/pt-br/assuntos/desenvolvimento-regional/comissao-permanente-para-o-desenvolvimento-e-a-integracao-da-faixa-de-fronteira. 
Cardim, M. F. M., Guirado, M. M., Dibo, M. R., \& Neto, F. C. (2016). Visceral leishmaniasis in the state of Sao Paulo, Brazil: spatial and space-time analysis. Revista de Saúde Pública, 50(48), 1-12. https://doi.org/10.1590/S1518-8787.2016050005965.

Cavalcante, F. R. A., Cavalcante, K. K. S., Florencio, C. M. G. D., Moreno, J. O., Correia, F. G. S., \& Alencar, C. H. (2020). Leishmaniose visceral humana: aspectos epidemiológicos, temporais e espaciais no Nordeste do Brasil, 2003-2017. Revista do Instituto de Medicina Tropical de São Paulo, 62 , e12.

Cavalcanti, O. L., Miranda, V. L., Lappa, F. P. F., Barbosa, D. B. S., Fortier, D. C., Nascimento, L. M. F., Barbosa, D. R. S., \& Soares, M. R. A. (2017). Aspectos da incidência de leishmaniose visceral humana e canina no município de Floriano/PI, Brasil. Revista Espacios, 38, 1-20.

Corumbá. (2021). Dados geográficos. Prefeitura do município de Corumbá. https://www.corumba.ms.gov.br/minha-corumba/dados-geograficos/

Costa, D. N. C. C., Bermudi, P. M. M., Rodas, L. A. C., Nunes, C. M., Hiramoto, R. M., Tolezano, J. E., Cipriano, R. S., Cardoso, G. C. D., Codeço, C. T., \& Chiaravalloti Neto, F. (2018). Human visceral leishmaniasis and relationship with vector and canine control measures. Revista de Saúde Publica, 52(92), 1-11. https://doi.org/10.11606/S1518-8787.2018052000381.

Courtenay, O., Peters, N. C., Rogers, M. E., \& Bern, C. (2017). Combining epidemiology with basic biology of sand flies, parasites, and hosts to inform leishmaniasis transmission dynamics and control. PLoS Pathogens, 13(10), 1-13. https://doi.org/10.1371/journal.ppat.1006571.

Dantas-Torres, F., Miró, G., Baneth, G., Bourdeau, P., Breitschwerdt, E., Capelli, G., Cardoso, L., Day, M. J., Dobler, G., Ferrer, L., Irwin, P., Jongejan, F., Kempf, V. A. J., Kohn, B., Lappin, M., Little, S., Madder, M., Maggi, R., Maia, C., \& Otranto, D. (2019). Canine Leishmaniasis Control in the Context of One Health. Emerging infectious diseases, 25(12), 1-4. doi: 10.3201/eid2512.190164. PMID: 31742505; PMCID: PMC6874277.

Graepp-Fontoura, I., Barbosa, D. S., Nascimento, L. F. C., Fontoura, V. M., Ferreira, A. G. N., Santos, F. A. A. S., Sousa, B. S., Santos, F. S., Santos-Neto, M., Dos Santos, L. H., \& Abreu-Silva, A. L. (2020). Epidemiological aspects and spatial patterns of human visceral leishmaniasis in Brazil. Parasitology, 147, 16651677 .

Instituto Brasileiro de Geografia e Estatística. (2010). Censo Brasileiro de 2010. https://censo2010.ibge.gov.br/.

Instituto Brasileiro de Geografia e Estatística. (2020). Cidades e Estados. https://www.ibge.gov.br/cidades-e-estados.

Lemos, M. D. A., Sousa, O. H., \& Silva, Z. S. S. B. (2019). Perfil da leishmaniose visceral no Brasil: uma revisão bibliográfica. Business and Technology Journal, 9(1), 93-114.

Lopez, L. F. B., Carneiro, L. E. P., Lope, A. L. K., Brighenti, K. B., Flores, E. F., Zuque, M. A. S, \& Lordelo, E. P. (2021). Epidemiologia da leishmaniose visceral no município de Três Lagoas - Mato Grosso do Sul, uma nova região endêmica no brasil. Brazilian Journal of Infectious Diseases, $25(1)$, 135. https://doi.org/10.1016/j.bjid.2020.101213.

Luz, J. G. G., Naves, D. B., Carvalho, A. G., Meira, G. A., Dias, J. V. L., \& Fontes, C. J. F. (2018). Visceral leishmaniasis in a Brazilian endemic area: an overview of occurrence, HIV coinfection and lethality. Revista do Instituto de Medicina Tropical de São Paulo, 60(12), 1-9. https://doi.org/10.1590/S16789946201860012.

Maia-Elkhoury, A. N. S., Valadas, S. Y. O. B., Nicholls, S., Buzanovsky, L. P., Vazquez, M. J. S., \& Salazar, A. M. R. (2021). Organização Pan-Americana da Saúde: Leishmanioses: Informe Epidemiológico nas Américas. Washington: Organização Pan-Americana da Saúde. https://iris.paho.org/bitstream/handle/10665.2/50505/2019-cde-leish-informe-epi-das-americas.pdf?seq

Menezes, J. A., Luz, T. C., Sousa, F. F., Verne, R. N., Lima, F. P., \& Margonari, C. (2016). Fatores de risco peridomiciliar e conhecimento sobre leishmaniose visceral na população de Formiga, Minas Gerais, Brasil. Revista Brasileira de Epidemiologia, 19(2), 362-374. https://doi.org/10.1590/1980-5497201600020013.

Oliveira, E. F., Oliveira, A. G., Arruda, C. C. P., Fernandes, W. S., \& Medeiros, M. J. (2020). Spatio-temporal modeling of visceral leishmaniasis in Midwest Brazil: An ecological study of 18-years data (2001-2018). PLoS One, 15(10), 1-20. https://doi.org/10.1371/journal.pone.0240218

Oliveira, E., Casaril, A. E., Fernandes, W. S., Ravanelli, M. S., Medeiros, M. J., Gamarra, R. M., Paranhos Filho, A. C., Oshiro, E. T., Oliveira, A. G., \& Galati, E. A. (2016). Monthly Distribution of Phlebotomine Sand Flies, and Biotic and Abiotic Factors Related to Their Abundance, in an Urban Area to Which Visceral Leishmaniasis Is Endemic in Corumbá, Brazil. PLoS One, 11(10), 1-17. https://doi.org/10.1371/journal.pone.0165155.

Oliveira, I. B., Batista, H. L., Peluzio, J. M., Pfrimer, I. A., Rodrigues, F. M., \& Carmo, J. R. (2014). Filho Epidemiological and environmental aspects of visceral leishmaniasis in children under 15 years of age between 2007 and 2012 in the City of Araguaína, State of Tocantins, Brazil. Revista da Sociedade Brasileira de Medicina Tropical, 47(4), 476-482. https://doi.org/10.1590/0037-8682-0099-2014.

Ortiz, R. C., \& Anversa, L. (2015). Epidemiologia da leishmaniose visceral em Bauru, São Paulo, no período de 2004 a 2012 : um estudo descritivo. Epidemiologia e Serviços de Saúde, 24(1), 97-104. https://doi.org/10.5123/S1679-49742015000100011.

Pêgo, B., \& Moura, R. (2018). Fronteiras do Brasil: uma avaliação de política pública. Ipea, 2018.

Rey, L. (2010). Noções básicas de parasitologia médica. 3rd ed. Editora Guanabara Koogan.

Rocha, L. (2019). Leishmanioses: conheça os insetos transmissores e saiba como se prevenir. Fundação Osvaldo Cruz. https://portal.fiocruz.br/noticia/leishmanioses-conheca-os-insetos-transmissores-e-saiba-como-se-prevenir\#: :text=Flebotom\%C3\%AD neos\%3A\% 20inset os $\% 20$ transmissores\&text=chagasi\%20\%C3\%A9\%20transmitido\%20pela\%20picada,pequenos\%20e\%20apresentam\%20colora\%C3\%A7\%C3\%A3o\%20amar elada.

Salomón, O. D., Feliciangeli, M. D., Quintana, M. G., Afonso, M. M. S., \& Rangel, E. F. (2015). Lutzomyia longipalpis urbanisation and control. Memórias do Instituto Oswaldo Cruz, 110(7), 831-846. https://doi.org/10.1590/0074-02760150207.

Silva, A. J. H. (2014). Metodologia de pesquisa: conceitos gerais. Unicentro. http://repositorio.unicentro.br:8080/jspui/bitstream/123 456789/841/1/Metodologia-da-pesquisa-cient\%C3\%ADfica-conceitos-gerais.pdf. 
Research, Society and Development, v. 10, n. 12, e549101220684, 2021

(CC BY 4.0) | ISSN 2525-3409 | DOI: http://dx.doi.org/10.33448/rsd-v10i12.20684

Silva, K. B. M., Castro, J. G. D., Calabrese, K., \& Seibert, K. S. (2017). Análise espacial da leishmaniose visceral no município de Palmas, Tocantins, Brasil. Revista Brasileira de Geografia Médica e da Saúde, 13(25), 18-29. https://doi.org/10.14393/Hygeia132502.

Toledo, C. R. S., Almeida, A. S., Miranda Chaves, S. A., Sabroza, P. C., Toledo, L. M., \& Caldas, J. P. (2017). Vulnerability to the transmission of human visceral leishmaniasis in a Brazilian urban area. Revista de Saúde Pública, 51(49), 1-11. https://doi.org/10.1590/S1518-8787.2017051006532.

Valverde, R. (2021). Doenças Negligenciadas. Brasil, Fundação Osvaldo Cruz. https://agencia.fiocruz.br/doen\%C3\%A7as-negligenciadas.

Zuben, A. P. B. V., \& Donalísio, M. R. (2016). Dificuldades na execução das diretrizes do Programa de Vigilância e Controle da Leishmaniose Visceral em grandes municípios brasileiros. Caderno de Saúde Pública, 32(6), 1-11. https://doi.org/10.1590/0102-311X00087415. 